\title{
Formulation and evaluation of controlled release antibiotic biodegradable implants for post operative site delivery
}

\author{
VIJAY MATHUR* \\ RAJESH MUDNAIK \\ LAXMIKANT BARDE \\ ARGHYA ROY \\ UMESH SHIVHARE \\ KISHORE BHUSARI \\ Sharad Pawar College of Pharmacy \\ Wanadongri, Hingna road \\ Nagpur-441110 (M.S.), India
}

\begin{abstract}
Biodegradable implants of ciprofloxacin hydrochloride for post operative site delivery were prepared using glyceryl monostearate and different concentrations of polyethylene glycol (PEG 6000), glycerol and Tween 80 as erosion enhancers by compression and molding technique. Formulations were subjected to in vitro drug release by the USP dissolution method, while promising formulations were subjected to in vitro drug release by the agar gel method and also to stability studies. It was observed that glyceryl monostearate formed hydrophobic matrix and delayed the drug delivery. Antibiotic release profile was controlled by using different combinations of erosion enhancers. The formulation prepared by the compression method showed more delayed release compared to formulations prepared by the molding method.
\end{abstract}

Keywords: biodegradable antibiotic implants, glyceryl monostearate, controlled drug release, site delivery, erosion enhancers

Systemic administration of antibiotics is an inherently inefficient method for achieving high local tissue concentration, because the vascular system distributes antibiotics uniformly throughout the entire body, only a fraction of the given dose reaches the site of infection (1). Direct application and local infusion of antibiotics into the surgical wound has been found to be more effective. However, the rapid absorption of antibiotics from the wound site reduces the duration of protection against infection, and local infusion is cumbersome and requires continuous medical attention. A biodegradable dosage form, which could be implanted at the site of surgical incision to release the drug over an extended period of time could be such a method. Extensive work has been done using poly D,L-(lactide-co-glycolide) and its derivatives as biodegradable polymer matrices; however, very little work was conducted using non-polymeric materials as biodegradable matrices. The implants containing poly D,L-(lactide-co-glycolide), Tween or Span and tomsulosin hydrochloride were prepared and their release was observed for up to 10 days by Mamun et al. (2). Localized treatment of osteomylitis by 6-week release of

\footnotetext{
* Correspondence; e-mail: mathurvb@gmail.com
} 
ciprofloxacin from implants using poly (D,L-lactide-co-glycolide) (50:50) was reported by Ramchandani et al. (3). A biodegradable long-acting contraceptive capsule-type implant was developed using biodegradable polyester, polycaprolactone as the principle matrix and a water-leachable polyether, Pluronic F68, as drug releasing enhancer (4). Levonorgestrel containing capsules showed an average levonorgestrel release rate of $7.0 \mu \mathrm{g}$ per day per $\mathrm{cm}$ length for a period of 2 years in rats. Baxter Healthcare Corp. (USA) has recently introduced a gentamicin implant using biodegradable polymers which may reduce incidences of surgical site infections and postoperative cast and complications (5).

Guse et al. (6) studied mass transport mechanism involved in the control of drug release from a lipid-based implant using different types of triglyceride (glyceryl trilaurate, glyceryl trimyristate, glyceryl tripalmitate and glyceryl tristearate) based cylinders which were prepared by the compression technique. Granules of glyceryl monostearate, polyethylene glycol (PEG 6000) and Tween 80 were mixed with the drug and compressed to form pellets, and then dry coated or compressed with glyceryl monostearate to form implant (7). After initial delay these multilayered implants disintegrate and the compressed mixture of granules containing glyceryl monostearate, polyethylene glycol, Tween 80 and powdered drug are exposed to the dissolution media. This may lead to a pulsatile drug delivery system. To provide a sustained-release drug delivery system the drug might be dispersed in the molten mass of glyceryl monostearate containing a release rate modifier.

In the present study biodegradable sustained-release implants for post operative drug delivery were prepared by dispersing ciprofloxacin hydrochloride in a molten mass of glyceryl monostearate as the biodegradable hydrophobic matrix having different concentrations of erosion enhancers such as PEG 6000, glycerol and Tween 80. To observe the variation in the drug release pattern, the release profile of the compressed formulation was compared with the molded formulation having the same composition and size.

\section{EXPERIMENTAL}

\section{Materials}

Ciprofloxacin hydrochloride was a gift sample from Adroit Pharmaceuticals Pvt. Ltd. (India), polyethylene glycol, Tween 80, glycerol, agar and potassium dihydrogen phosphate were purchased from Adroit Pharmaceuticals Pvt. Ltd. Glyceryl monostearate was supplied by Suyog Chemicals Pvt. Ltd. (India) and all other chemicals used were of laboratory reagents/analytical reagents grade.

\section{Preparation of antibiotic loaded implants}

Compression technique. - Glyceryl monostearate, PEG 6000 and glycerol or Tween 80 in specified quantities (Table I) were heated to $70{ }^{\circ} \mathrm{C}$ on a water bath under stirring with a glass rod. The weighed quantity of the drug was dispersed uniformly just before the mass solidified. The solidified blend was stored in freezer for $1 \mathrm{~h}$, the hard mass was ground to fine powder and passed through a sieve (aperture $0.42 \mathrm{~mm}$ ). The granules were compressed on a rotary compression machine, punch size $8 \mathrm{~mm}$ (flat), to form tablet shaped pellets. Different formulations were prepared using various glycerol or Tween 80 concentrations. 
Molding technique. - The molten mass and the various formulations were prepared (Table 1) as above, except that the molten mass was drawn up into a $10 \mathrm{~mL}$-syringe and injected into a cylindrical stainless steel mould of $8 \mathrm{~mm}$ diameter. The mould was allowed to cool and each cylindrical pellet was cut into 3-mm long pieces equivalent to the thickness of pellets prepared by the compression technique, to make the same size pellets by both techniques.

\section{In vitro evaluation}

The release of ciprofloxacin was studied by USP (8) (Disso 2000, paddle method at $50 \mathrm{rpm})$ at $37{ }^{\circ} \mathrm{C}$ in $900 \mathrm{~mL}$ of $\mathrm{pH} 7.4\left(0.1 \mathrm{~mol} \mathrm{~L}^{-1}\right)$ phosphate buffer. Samples were filtered and analyzed spectrophotometrically at $276 \mathrm{~nm}$ (Shimadzu 1601, Japan).

\section{Gel simulating in vitro implantation (gel method)}

In vitro release was followed by placing the pellet implant in agar gel simulating subcutaneous tissue conditions with respect to viscosity and water content (9). Agar crystals were dissolved in boiling $0.1 \mathrm{~mol} \mathrm{~L}^{-1}$ phosphate buffer $\mathrm{pH} 7.4$, to prepare $1.5 \%$ an agar solution, which was poured into a Petri dish and left to congeal. A hole $(8 \mathrm{~mm})$ was drilled in the center of the agar plate with a cork borer and the pellet/implant was placed in the hole. Sufficient quantity of hot $\left(50-60{ }^{\circ} \mathrm{C}\right)$ agar solution was poured on the top to

Table I. Formulations of compressed and molded implants using erosion enhancers

\begin{tabular}{rcccccc}
\hline \multirow{2}{*}{ Sample } & Formulation & \multicolumn{5}{c}{ Ingredient (\%) } \\
\cline { 5 - 7 } & & Drug & GMS & PEG 6000 & Tween 80 & Glycerol \\
\hline & Compressed & & & & & \\
1 & C1 & 20.0 & 40.0 & 40.0 & 0.0 & 0.0 \\
2 & C2 & 20.0 & 40.0 & 37.5 & 2.5 & 0.0 \\
3 & C3 & 20.0 & 40.0 & 35.0 & 5.0 & 0.0 \\
4 & C4 & 20.0 & 40.0 & 32.5 & 7.5 & 0.0 \\
5 & C5 & 20.0 & 40.0 & 37.5 & 0.0 & 2.5 \\
6 & C6 & 20.0 & 40.0 & 35.0 & 0.0 & 5.0 \\
7 & C7 & 20.0 & 40.0 & 32.5 & 0.0 & 7.5 \\
& Molded & & & & & \\
8 & M1 & 20.0 & 40.0 & 40.0 & 0.0 & 0.0 \\
9 & M2 & 20.0 & 40.0 & 35.0 & 5.0 & 0.0 \\
10 & M3 & 20.0 & 40.0 & 25.0 & 15.0 & 0.0 \\
11 & M4 & 20.0 & 40.0 & 10.0 & 30.0 & 0.0 \\
12 & M5 & 20.0 & 40.0 & 10.0 & 0.0 & 30.0 \\
13 & M6 & 20.0 & 40.0 & 10.0 & 15.0 & 15.0 \\
\hline
\end{tabular}

GMS - glyceryl monostearate

PEG 6000 - polyethylene glycol 6000 
cover the implants and left to congeal. The plate was covered and placed in the oven (37 $\left.{ }^{\circ} \mathrm{C}\right)$. Several agar plates implanted with ciprofloxacin devices were prepared at the same time and the samples were collected at 6, 24, 48, 72, $96 \mathrm{~h}$. At each sampling time, one plate was removed from the oven. The plate was divided into four sampling zones and three samples were removed from each zone using a size 4 cork borer ( $8 \mathrm{~mm}$ in diameter). The samples were accurately weighed and dissolved in boiling buffer containing 25 $\% \mathrm{NaCl}$. The solution was cooled in an ice bath to precipitate the agar.

\section{Stability studies}

Formulations C3 and M2 (both containing $5.0 \%$ of Tween 80, six of each), were wrapped in aluminum foil, sealed and kept for stability studies as per ICH guidelines (10), under conditions $40 \pm 2{ }^{\circ} \mathrm{C} / 75 \pm 5 \% \mathrm{RH}$. Every month, one sample from each formulation was withdrawn and estimated for drug concentration. Weighted formulation was crushed and dissolved in $0.1 \mathrm{~m} \mathrm{~mol} \mathrm{~L}^{-1} \mathrm{HCl}$ under stirring for $2 \mathrm{~h}$ and the drug concentration was calculated.

\section{RESULTS AND DISCUSSION}

Formulation prepared by the compression technique C1 (containing $40.0 \%$ PEG 6000) showed up to $59.0 \%$ of drug release in $36 \mathrm{~h}$. Formulation C6 containing $5.0 \%$ glycerol showed $93.8 \%$ of drug release in $36 \mathrm{~h}$ compared to $75.2 \%$ from C3 containing the same concentration of Tween 80 . Higher drug release from implants containing erosion enhancers may be due to the solubility of erosion enhancers leading to higher porosity of the formulation. Agitation also helps the formulation to disintegrate and provide a larger surface area to enhance drug release. In the case of formulations containing glycerol, higher percentage of drug release was observed because of the higher hydrophilicity of glycerol compared to the formulations containing Tween 80 (Fig. 1a). Increasing the concentration of Tween 80 (C4) or glycerol (C7) from 5.0 to $7.5 \%$ led to soft and sticky formulations causing difficulty in compression; hence these were not used in further studies.

Uncompressed formulations prepared by the molding technique showed faster dissolution due to higher erosion during dissolution. Formulation M1 (containing $40.0 \%$ PEG 6000) showed $73.5 \%$ drug release, while the formulation containing $5.0 \%$ of Tween 80 (M2) showed higher drug release of $81.0 \%$ in 36 h. Formulation M6 containing equal proportions of glycerol and Tween 80 (15.0\% each) showed intermediate release compared to formulations M4 and M5 containing $30.0 \%$ of either Tween 80 or glycerol (Fig. 1b). Delayed drug release from compressed formulations was observed compared to molded formulations, which could be due to the compactness in the dosage form leading to a reduction in porosity, lower erosion and penetration of dissolution fluid into the dosage form.

In vitro drug release kinetics of the formulations prepared by the compression technique (C3) and molding technique (M2) were analyzed by PCP Disso V-3 software (Poona College of Pharmacy, Pune, India). 
Considering the release pattern from the formulations C3 (containing $5.0 \%$ of Tween 80) prepared by the compression technique and similar formulation M2 (containing identical percentage of Tween 80) prepared by the molding technique were selected for evaluation by the gel simulation method.

Release of ciprofloxacin hydrochloride from glyceryl monostearate matrixes in the gel method was conducted in order to stimulate the in vivo implantation conditions, un-

a)

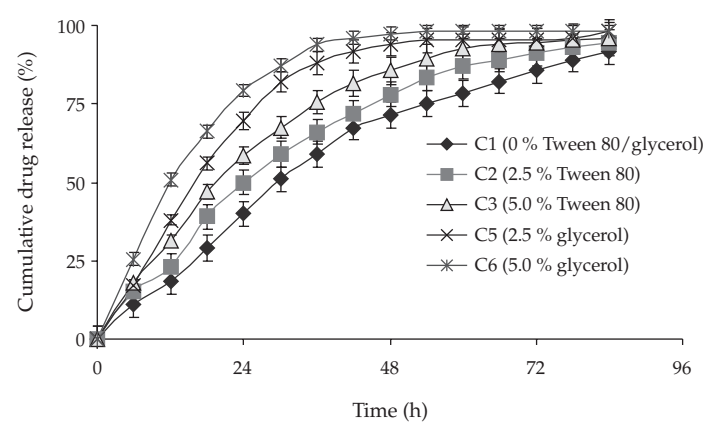

b)

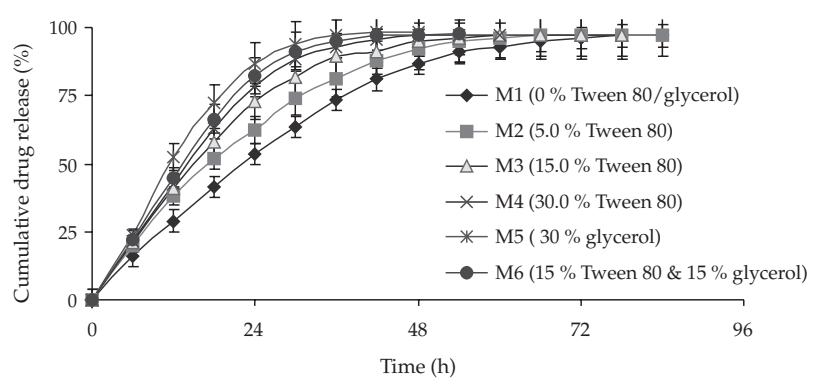

c)

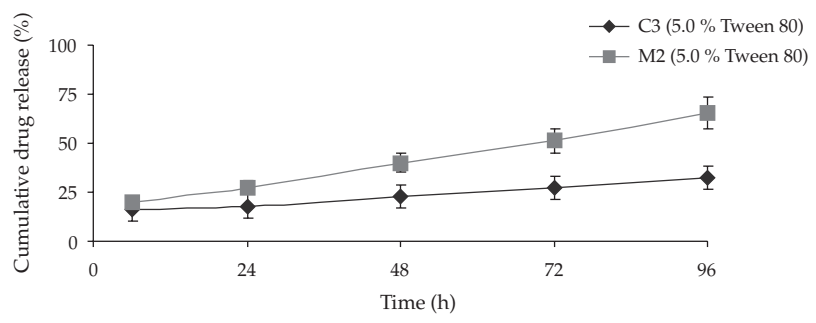

Fig. 1. Comparative in vitro ciprofloxacin hydrochloride release profiles from formulations prepared by: a) compression method, b) molding method, c) C3 and M2 (both containing $5.0 \%$ Tween 80) from agar gel. For composition see Table I. Each point denotes mean \pm SD, $n=3$. 
der which the implanted matrixes are surrounded by tissues rather than by aqueous solution. Drug release from the insoluble matrix is generally achieved by penetration of the release medium into the matrix and dissolution of the drug, followed by diffusion of the drug solution through the channels and pores of the matrix.

The drug release from formulations C3 and M2 (both containing $5.0 \%$ Tween 80 ) in agar gel simulating subcutaneous tissue resulted in significant difference in the drug release pattern compared to the release pattern in dissolution studies. Pellets prepared by the molding technique using $5.0 \%$ Tween 80 (M2) showed $65.5 \%$ higher drug release as compared to the pellets prepared by the compression technique, $32.5 \%$ in $96 \mathrm{~h}$ (Fig. 1c). In the agar gel method, drug release taken place by diffusion; a layer close to the implant has higher drug concentration and is inversely proportional to the distance. Percentage diffusion of the drug in the absence of any agitation is also dependent on the solubility of the drug in the aqueous phase.

The commonly adopted model for understanding the release behaviour of the drug from an inplant is the Korsmeyer-Peppas equation. The release exponent $n$ is releated to the drug release mechanism; the values of 0.6491 and 0.6022 for C3 and M2 (11) resp. indicate anomalous transport (diffusion coupled with the erosion mechanism). $R^{2}$ values of linear regression for the Higuchi plot were 0.9852 and 0.9786 for C3 and M2, resp., indicating that the data fit best the Higuchi model.

The values of $n$ in the agar gel method were 0.2441 and 0.4188 for C3 and M2, resp., indicating Fickian transport (diffusion mechanism). The $R^{2}$ values for the Higuchi plot were 0.9649 and 0.9885 for C3 and M2, resp. This system was also best presented by the Higuchi model.

In accelerated stability studies, both formulations C3 and M2, having the same composition but differing in the preparation technique, remained stable enough over the designated period under accelerated conditions $\left(40 \pm 2{ }^{\circ} \mathrm{C} / 75 \pm 5 \% \mathrm{RH}\right)$. The initial drug concentration remained constant for a month and dropped by 0.6 and $0.4 \%$, resp. after 3 months and by 1.5 and $1.3 \%$, resp. after 6 months.

\section{CONCLUSIONS}

On the basis of the results obtained, it can be concluded that glyceryl monostearate forms the hydrophobic matrix for a controlled drug delivery system. Formulations prepared by the compression or molding technique can be implanted subcutaneously at the site of surgery to prevent postoperative infection. The dissolution profile of formulations can be controlled by the use of an erosion enhancer and by the preparation technique. In subcutaneous implantation, the release pattern is dependent on the preparation technique as well as on the solubility of the drug in the aqueous phase.

Acknowledgements. - The Authors are thankful to Adroit Pharmaceuticals Pvt. Ltd. (India) for providing ciprofloxacin and to Suyog Chemicals Pvt. Ltd. (India) for providing glyceryl monostearate. The authors also thank the management of Sharad Pawar College of Pharmacy for their timely support. 
V. Mathur et al.: Formulation and evaluation of controlled release antibiotic biodegradable implants for post operative site delivery, Acta Pharm. 60 (2010) 111-117.

\section{REFERENCES}

1. C. Schmidt, R. Wenz, B. Nies and F. Moll, Antibiotic in vivo/in vitro release, histocompatibility and biodegradation of gentamycin implants on lactic acid polymers and copolymers, J. Control. Rel. 37 (1995) 83-94; DOI: 10.1016/0168-3659(95)00067-1.

2. M. E. A. Mamun, H. A. Khan, I. Dewan and R. U. Jalil, In vitro study on tamsulosin release kinetics from biodegradable PLGA in situ implants, Pak. J. Pharm. Sci. 22 (2009) 360-367.

3. M. Ramchandani and D. Robinson, In vitro and in vivo release of ciprofloxacin from PLGA 50:50 implants, J. Control. Rel. 54 (1998) 167-175; DOI: 10.1016/s0168-3659(97)00113-2.

4. P. Y. Wang, C. X. Song, H. F. Sun, H. L. Shi and R. W. Shi, A biodegradable long-term contraceptive implant, Eng. Med. Biol. Soc. 6 (1998) 2901-2904; DOI: 10.1109/IEMS.1998.746093.

5. http://www.surgistrategies.com/hotnews/baxter-agreement-with-innocall-implant.html; access date January 11, 2010.

6. C. Guse, S. Koennings, F. Kreye, F. Siepmann, A. Goepferich and J. Siepmann, Drug release from lipid-based implants: Elucidation of the underlying mass transport mechanisms, Int. J. Pharm. 314 (2006) 137-144; DOI: 10.1016/j.i.jpharm.2005.08.030.

7. J. C. Shah and S. Allababidi, Glyceryl Monostearate Based Biodegradable Implants for Site Specific Delivery of Drugs, U.S. Pat. 5,891,456, 6 Apr 1999; ref. Chem. Abstr. 130 (1999) $271997 f$.

8. United States Pharmacopoeia 30, National Formulary 25, United State Pharmacopeial Convection, Rockville 2007, pp. 1759-1760.

9. S. Allababidi and J. Shah, Kinetic and mechanism of release from glyceryl monostearate based implants: Evaluation of release in a gel simulating in vivo implantations, J. Pharm. Sci. 87 (1998) 169-172; DOI: 10.1021/js9703986.

10. ICH Harmonised Tripartite Guideline, Stability Testing of New Drug Substances and Products, Q1A (R2), Current Step 4 version, 6 February 2003.

11. P. Costa and J. M. S. Lobo, Modeling and comparison of dissolution profiles, Eur. J. Pharm. Sci. 13 (2001) 123-133.

\section{$S A \check{Z} E T A K$}

\section{Priprava i vrednovanje biorazgradljivih implantata s kontroliranim oslobađanjem za postoperativnu primjenu}

VIJAY MATHUR, RAJESH MUDNAIK, LAXMIKANT BARDE, ARGHYA ROY, UMESH SHIVHARE i KISHORE BHUSARI

Biorazgradljivi implantati ciprofloksacin hidroklorida za postoperativnu primjenu pripravljeni su pomoću gliceril monostearata (GMS) i različitih koncentracija polietilen glikola (PEG 6000), glicerola i Tween 80 kao promotora erozije metodom kompresije i lijevanja. Oslobađanje ljekovite tvari iz pripravaka praćeno je in vitro prema USP metodi. Pripravci koji su dali dobre rezultate ispitani su i in vitro metodom s agarom te su podvrgnuti testovima stabilnosti. Primijećeno je da gliceril monostearat tvori hidrofobni matriks i usporava oslobađanje lijeka. Koristeći različite kombinacije promotora erozije postignuto je kontrolirano oslobađanje antibiotika. Oslobađanje iz implantata dobivenih metodom kompresije sporije je od implantata dobivenih metodom lijevanja.

Ključne riječi: biorazgradljivi implantati antibiotika, gliceril monostearat, kontrolirano oslobađanje, mjesto isporuke, promotor erozije

Sharad Pawar College of Pharmacy, Wanadongri, Hingna road, Nagpur-441 110 (M.S.), India 